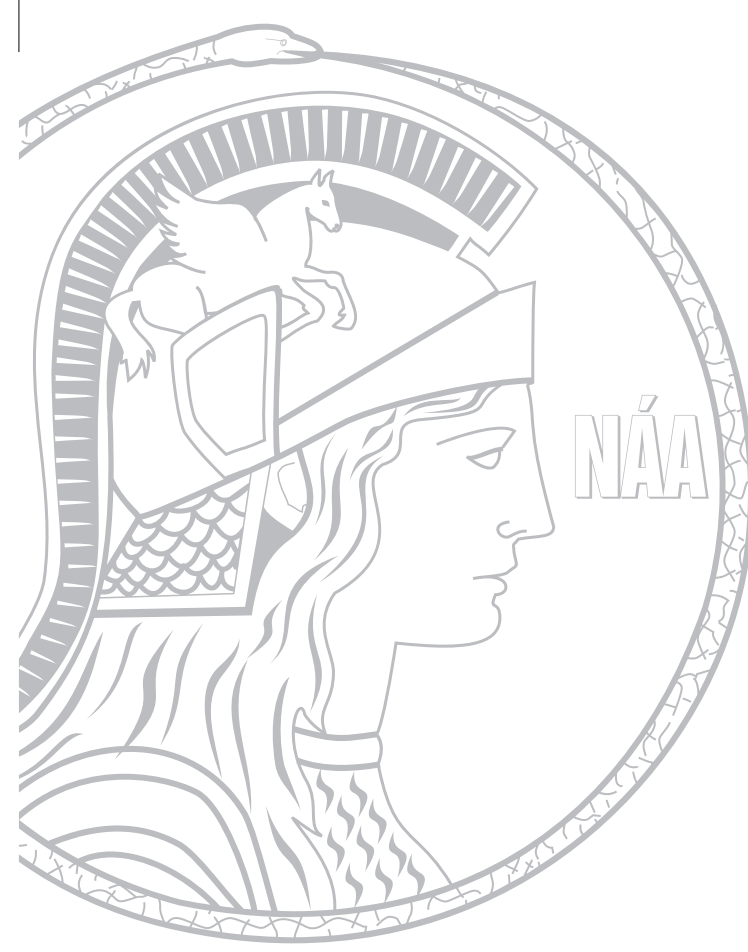

An Acad Bras Cienc (2020) 92(Suppl. 2): e20191524 DOI 10.1590/0001-3765202020191524
Anais da Academia Brasileira de Ciências I Annals of the Brazilian Academy of Sciences
Printed ISSN 0001-3765 I Online ISSN 1678-2690

www.scielo.br/aabc | www.fb.com/aabcjournal

BIOLOGICAL SCIENCES

\title{
Tephritidae flies associated with Chuquiraga avellanedae (Asteraceae) in Patagonia, Argentina
}

\author{
FERNANDO J. MARTINEZ, ALLEN L. NORRBOM, PABLO SCHLISERMAN \& \\ MARÍA VICTORIA CAMPANELLA
}

\begin{abstract}
In Patagonia, knowledge about the interaction among tephritids and the native flora is very scarce. In this study we identified for the first time two tephritid species (Cecidochares sp. and Neosphaeniscus m-nigrum) associated with the capitula of Chuquiraga avellanedae. This is the first record of a host plant for the genus Neosphaeniscus. Cecidochares sp. was more abundant and had a shorter development time than N. m-nigrum. Also, two families of parasitoid wasps (Pteromalidae and Eurytomidae) were registered. Further studies are needed to understand the impact of these tephritids on C. avellanedae fitness and their potential to control its populations.
\end{abstract}

Key words: Biological control, encroachment, host plant, insect-plant interaction, nonfrugivorous Tephritids.

\section{INTRODUCTION}

With 4968 recognized species, the Tephritidae are among the larger families of Diptera (Norrbom et al. 1999, Norrbom 2010, Savaris et al. 2016, Borkent et al. 2018, Brown et al. 2018). Larvae of most species of the subfamily Tephritinae feed almost exclusively on plants of the family Asteraceae (Prado et al. 2002, Norrbom 2010, Savaris et al. 2015). In Argentina, 171 species of Tephritidae belonging to 34 genera have been registered (A.L. Norrbom, unpublished data), but knowledge of the fauna is based primarily on old, incomplete surveys, and there are large gaps in knowledge of the host plant relationships, especially in the native flora (Bartolucci 2008).

Chuquiraga avellanedae Lorentz (Asteraceae) is an evergreen perennial shrub of Patagonian steppes (Bisigato et al. 2016). Some studies have indicated that $C$. avellanedae density has increased mainly as a consequence of overgrazing by sheep (Beeskow et al. 1995,
Campanella et al. 2016). Understanding the potential impact of tephritid flies on C. avellanedae fitness could be a useful tool for the control and management of the populations of this shrub. The objective of this work was to identify for the first time tephritid fly species associated with capitula of $C$. avellanedae.

Sampling was made at Playa Paraná ( $42^{\circ} 47^{\prime} 43^{\prime \prime}$ S; $64^{\circ} 57^{\prime} 12^{\prime \prime} \mathrm{W}$; Fig. 1), a site belonging to the Patagonia Phytogeographical Province (Bisigato et al. 2016). Field work was carried out during one C. avellanedae blooming season (Dec 2016-Feb 2017). At the beginning of January, we randomly harvested branches with inflorescences. They were placed in plastic bags and transferred to the laboratory. Then, we searched for larvae and/or pupae in the capitula using a stereomicroscope. After corroborating the presence of immature stages of insects, we returned to the field at the end of January and beginning of February to collect inflorescences and transferred them to the 


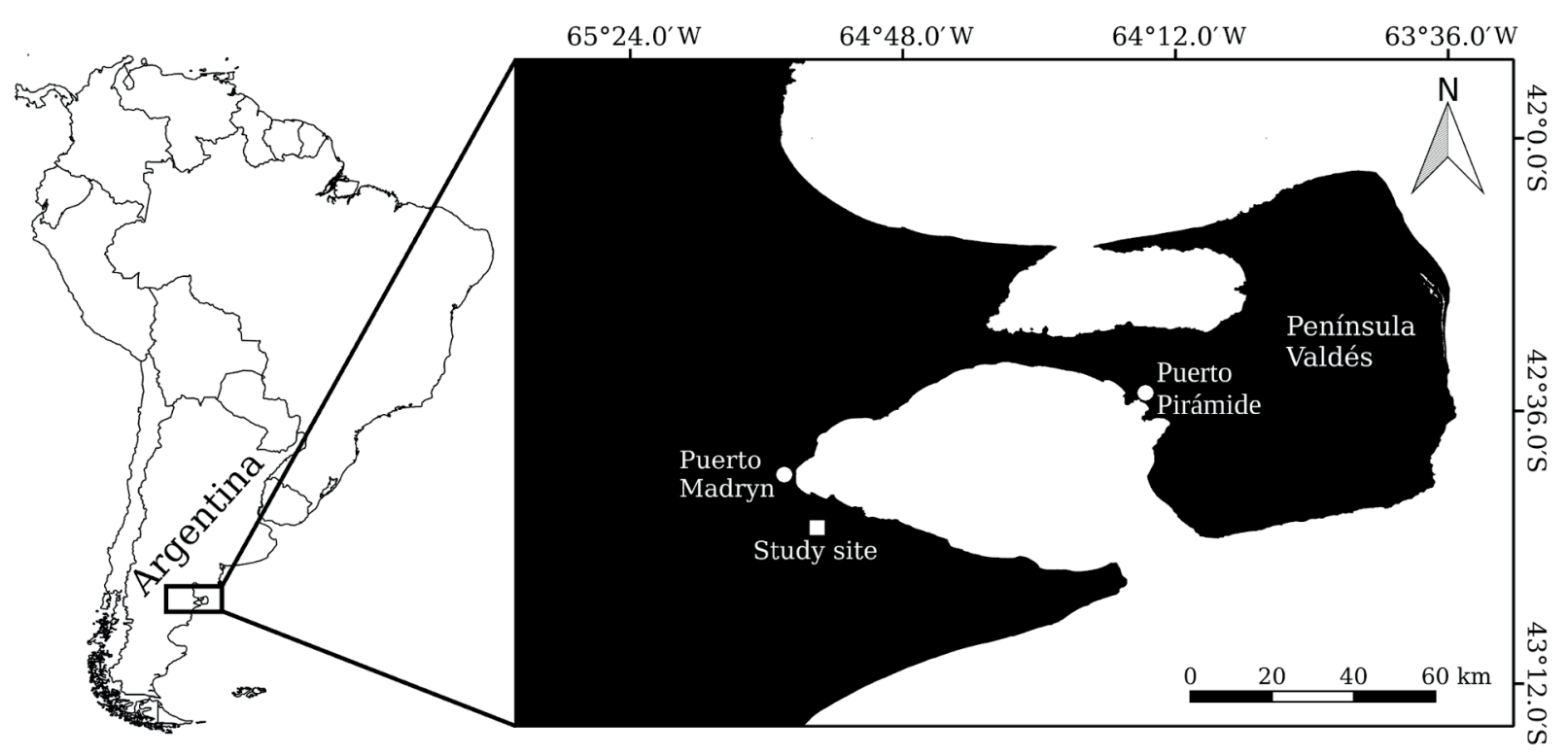

Figure 1. Location of the study site in the northeast of Patagonia, Argentina.

Laboratory of Terrestrial Fauna of the Instituto Patagónico para el Estudio de los Ecosistemas Continentales (IPEEC-CONICET). Inflorescences were carefully dissected and pupae were put in plastic containers with a fine mesh in the top. The containers were kept at room temperature, under ambient conditions for nine months. Fly or parasitoid emergence was periodically checked, and after emergence adults were killed in 70\% ethanol. Voucher specimens were deposited in the Entomological Collection of the IPEEC-CONICET (voucher numbers: CNP-CE 1476/1485). Tephritid species were identified by Allen L. Norrbom. The map was made with QGIS 2.14.18 (QGIS Development Team 2016). All figures were edited with GIMP 2.8.20 (GIMP Development Team 2017).

Among 42 inspected inflorescences, 54.76\% were found to have immature tephritid larvae, 9.53\% had lepidopteran larvae, and 35.71\% had no insects. The number of tephritid specimens per capitula were 1 larva (43.48\%), 2 larvae (34.78\%) or 3 larvae (21.23\%).

The capitula were infested by two tephritid species. From the total of 110 incubated tephritid pupae, adults of an undescribed species of Cecidochares (Fig. 2a) emerged from $24.5 \%$, and adults of Neosphaeniscus m-nigrum (Hendel) (Fig. 2b) emerged from $2.7 \%$. The others died or were parasitized. The average time of emergence for Cecidochares sp. was 209 days ( $\pm \pm S E ; n=27)$ and for N. m-nigrum was 269 days ( $13 \pm S E ; n=3$ ).

About seven percent of the tephritid pupae were parasitized by solitary parasitoid wasps belonging to the families Pteromalidae and Eurytomidae. The Pteromalidae species emerged in two periods, during the end of summer (18 days \pm 8 ) and the next spring (295 days \pm 18$)$ after the emergence of tephritid species (Fig. 2c). Eurytomidae was represented by a single individual of the genus Eurytoma, which emerged the next spring (230 days) (Fig. 2d).

The results of this study report for the first time two tephritid flies associated with C. avellanedae, a representative shrub of the Patagonian Phytogeographical region. These tephritid species were also reared from $C$. avellanedae near the study area (Chubut: Puerto Pirámide, Península Valdés; Fig. 1) during 

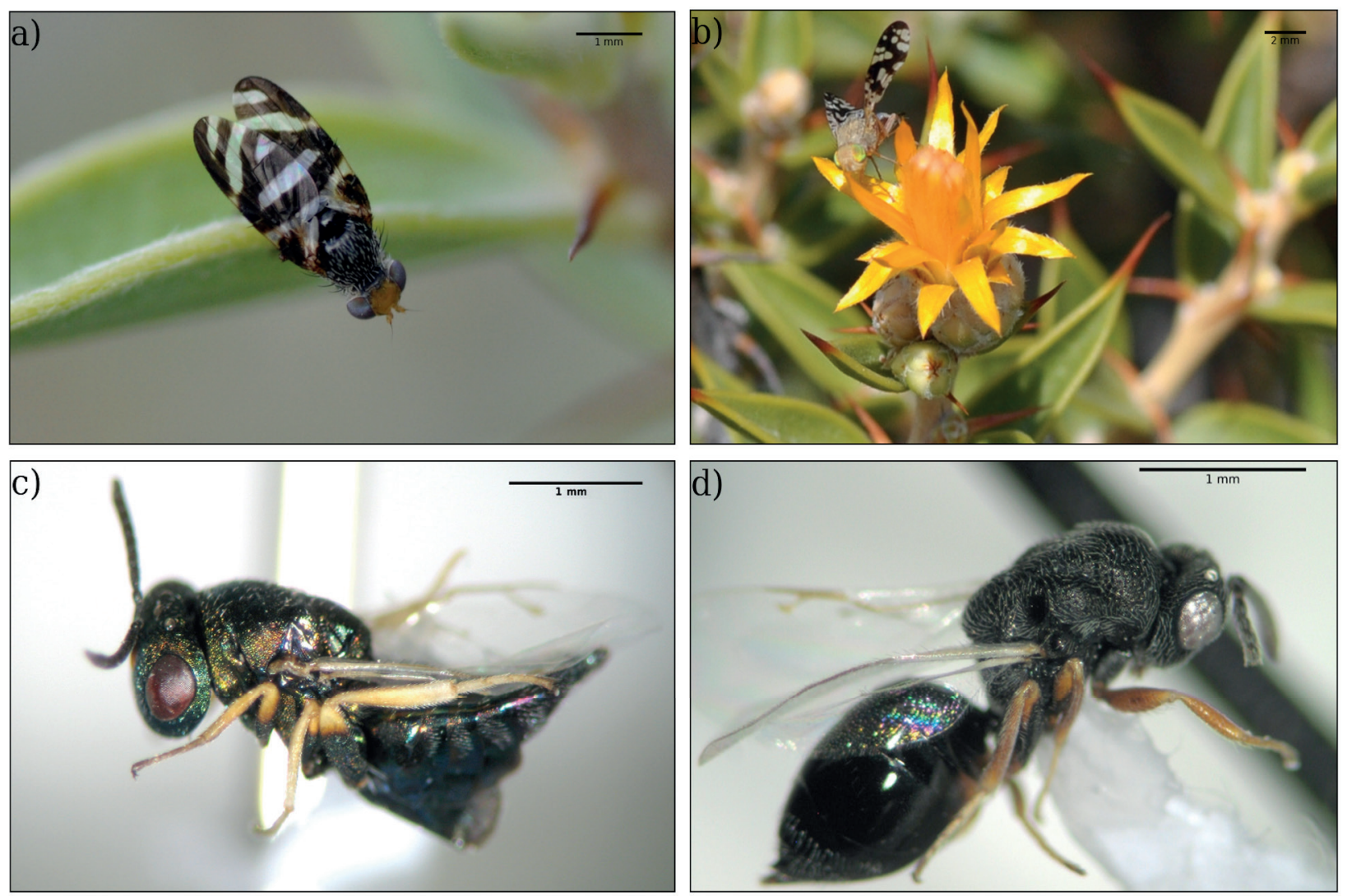

Figure 2. Cecidochares sp. on foliage of Chuquiraga avellanedae (a), Neosphaeniscus m-nigrum on capitula of $C$. avellanedae (b), adult of Pteromalidae (c), and Eurytoma sp. (d).

1993-1995 (D.E. Gandolfo, unpublished data, specimens in National Museum of Natural History, Smithsonian Institution, Washington, DC). This is the first host plant record for the genus Neosphaeniscus. Females of Cecidochares sp. and Neosphaeniscus m-nigrum lay eggs in developing flowerheads of C. avellanedae. Generally, no achenes are produced in infested capitula.

There is evidence of Tephritinae species affecting plant fitness (Edwards et al. 2009), and some species are used in programs of biological control of weeds (Woodburn 1993, Turner et al. 1994, Van Driesche et al. 2008). Moreover, the majority of nonfrugivorous species used for biological control belong to the subfamily Tephritinae associated with Asteraceae (Karimpour 2011). For example, the stem gall fly
Cecidochares connexa (Macquart) has been used as a successful biocontrol agent of the invasive weed Chromolaena odorata (L.) R. M. King \& H. Rob. in Africa, Asia and the Pacific (McFadyen et al. 2003, Zachariades et al. 2009, AigbedionAtalor et al. 2018).

Other tephritid species also have been found associated with local species of Asteraceae; Plaumannimyia valdesiana (Gandolfo \& Norrbom) was reared from capitula of Gutierrezia solbrigii, whereas Rachiptera baccharidis (Rondani) produced stem galls on Gutierrezia spp., Baccharis spp. and Grindelia chiloensis (Cornel.) Cabrera (Cordo \& DeLoach 1992, Gandolfo \& Norrbom 1997). Trupanea patagonica Brethes was also recorded in Chubut; larvae of this species were collected from capitula of G. solbrigii Cabrera and Grindelia 
spp. (Cordo \& DeLoach 1992). In this study, a Trupanea sp. was observed in the field, foraging from capitula of $C$. avellanedae, but no adults of that fly emerged from the pupae collected.

The tephritid species reared from $C$. avellanedae are clearly univoltine. At the end of summer larvae pupated inside the capitula. Before spring the capitula detached from the shrubs and fell to the ground, and adults emerged the next spring. Generally, in temperate regions univoltine species predominate (Bartolucci 2008). Pupal diapause can be conceived as an overwintering strategy to cope with an extended period of adverse conditions (Kostal 2006).

Cecidochares sp. and N. m-nigrum differed in emergence time under laboratory conditions. In accordance with this, Cecidochares sp. was observed in the field earlier in the season F.J. Martinez \& M.V. Campanella, personal observation. Thus, Cecidochares sp. could attack flowerheads earlier than N. m-nigrum. This pattern could be related to different strategies for the exploitation of resources (Dzul-Cauich et al. 2014, Straw 1989a). There is evidence that when two species share the same host, they usually differ in oviposition time and larval establishment using distinct phases of flowerheads development (Straw 1989b). Moreover, Cecidochares sp. was reared from two other species of Chuquiraga (C. aurea Skottsb. and C. erinacea D. Don; Gandolfo D.E., Velazquez and Calcaterra, unpublished data, specimens in National Museum of Natural History, Smithsonian Institution, Washington, DC) suggesting that Cecidochares sp. uses a broader range of host plant species than N. m-nigrum.

The two families, Pteromalidae and Eurytomidae, have been registered as parasitoids of tephritid species in other studies (Mena-Correa et al. 2008, Ovruski \& Schliserman 2012). The Pteromalidae species was the most abundant and apparently has a bivoltine strategy, with two generations, one of rapid development or short cycle and another with a winter diapause. This strategy is frequently observed in parasitoids from temperate regions ( $\mathrm{He}$ et al. 2010). The emergence of some parasitoids later than their adult tephritid hosts observed in this study has been observed in other studies (Ovruski et al. 2007).

Additional studies are needed to understand infestation patterns of Cecidochares sp. and N. m-nigrum and more exhaustive sampling of other host plants is also required for better knowledge of the biology of these species. A significant proportion ( $>54 \%$ ) of C. avellanedae inflorescences were occupied by tephritid larvae. This appears to reduce seed production and subsequent dispersion, possibly acting as a constraint on the abundance of $C$. avellanedae. However, more studies are needed to provide a comprehensive view of the impact of these flies on the reproductive success of $C$. avellanedae.

\section{Acknowledgments}

We thanks Daniel A. Aquino (FCNyM-UNLP) for confirming the determination of parasitoids. Collection permits were awarded by the Dirección de Flora y Fauna Silvestre de la Provincia del Chubut (File No. 2270/17; Provision No. 48/08 DFyFS). This study was supported by Consejo Nacional de Investigaciones Científicas y Técnicas (PUE-IPEEC CONICET No. 22920160100044). Marcoandre Savaris and two anonymous reviewers provided thoughtful comments on the manuscript. Mention of trade names or commercial products in this publication is solely for the purpose of providing specific information and does not imply recommendation or endorsement. 


\section{REFERENCES}

AIGBEDION-ATALOR PO, WILSON DD, EZIAH VY, DAY MD \& PETERSON ID. 2018. The Distribution and abundance of the stem-galling fly, Cecidochares connexa (Macquart) (Diptera: Tephritidae), a biological control agent of Chromolaena odorata (L.) (Asteraceae), in Ghana. Afri Entomol 26: 471-480.

BARTOLUCCI AF. 2008. Tephritidae. In: Claps LE, Debandi $\mathrm{G}$ and Roig-Juñent S (Eds), Biodiversidad de Artrópodos Argentinos volumen 2. Editorial Sociedad Entomológica Argentina, Mendoza, p. 271-279.

BEESKOW AM, ELISSALDE NO \& ROSTAGNO CM. 1995. Ecosystem changes associated with grazing intensity on the Punta Ninfas rangelands of Patagonia, Argentina. J Range Manag 48: 517-522.

BISIGATO AJ, HARDTKE LA, DEL VALLE HF, BOUZA PJ \& PALACIO RG. 2016. Regional-scale vegetation heterogeneity in northeastern Patagonia: Environmental and spatial components. Community Ecol 17: 8-16.

BORKENT A ET AL. 2018. Remarkable fly (Diptera) diversity in a patch of Costa Rican cloud forest: Why inventory is a vital science. Zootaxa 4402(1): 53-90.

BROWN BV ET AL. 2018. Comprehensive inventory of true flies (Diptera) at a tropical site. Commun Biol 1: 21.

CAMPANELLA MV, BISIGATO AJ \& ROSTAGNO CM. 2016. Plant production along a grazing gradient in a semiarid Patagonian rangeland, Argentina. Plant Ecol 217: 1553-1562.

CORDO HA \& DELOACH J. 1992. Occurrence of snakeweeds (Gutierrezia: Compositae) and their enemies in Argentina: implications for biological control in the United States. Biol Control 2: 143-158.

DZUL-CAUICH JF, HERNÁNDEZ-ORTIZ V, PARRA-TABLA V \& RICO-GRAY V. 2014. Seasonal dynamics of the flower head infestation of Smallanthus maculatus by two nonfrugivorous Tephritids. J Insect Sci 14: 189.

EDWARDS PB, ADAIR RJ, HOLTKAMP RH, WANJURA WJ, BRUZZESE AS \& FORRESTER RI. 2009. Impact of the biological control agent Mesoclanis polana (Tephritidae) on bitou bush (Chrysanthemoides monilifera subsp. rotundata) in eastern Australia. Bull Entomol Res 99: 51-63.

GANDOLFO DE \& NORRBOM AL. 1997. A new species of Trypanaresta Hering (Diptera: Tehritidae) from Patagonia, a potential agent for biological control of snakeweeds (Gutierrezia spp.) in the United States. Proc Entomol Soc Wash 99: 248-256.
GIMP DEVELOPMENT TEAM. 2017. GNU Image Manipulation Program. Available at: https://www.gimp.org/.

HE XZ, WANG Q, WALKER JTS, ROGERS DJ \& LO PL. 2010. A sophisticated life history strategy in a parasitoid wasp: Producing univoltine and multivoltine phenotypes in a local population. Biol Control 54: 276-284.

KARIMPOUR Y. 2011. Fruit flies (Dip.: Tephritidae) reared from capitula of Asteraceae in the Urmia region, Iran. Journal of Entomological Society of Iran 30: 53-66.

KOSTAL V. 2006. Eco-physiological phases of insect diapause. J Insect Physiol 52: 113-127.

MCFADYEN REC, DESMIER DE CHENON R \& SIPAYUNG A. 2003. Biology and host specificity of the chromolaena stem gall fly, Cecidochares connexa (Macquart) (Diptera: Tephritidae). Aust J Entomol 42: 294-297.

MENA-CORREA J, SIVINSKI J, GATES M, RAMÍREZ-ROMERO R \& ALUJA M. 2008. Biology of Eurytoma Sivinskii, an Unusual Eurytomid (Hymenoptera) Parasitoid of Fruit fly (Diptera: Tephritidae) Pupae. Fla Entomol 91(4): 598-603.

NORRBOM AL, CARROLL LE, THOMPSON FC, WHITE IM \& FREIDBERG A. 1999. Systematic Database of Names. In: Thompson FC (Ed), Fruit Fly Expert Identification System and Systematic Information Database. Myia 9: 65-251.

NORRBOM AL. 2010. Tephritidae (fruit flies, moscas de frutas). In: Brown BV, Borkent A, Cumming JM, Wood DM, Woodley NE and Zumbado MA (Eds), Manual of Central American Diptera, volume 2. NRC Research Press, Ottawa, p. 909-954.

OVRUSKI SM \& SCHLISERMAN P. 2012. Biological control of Tephritid fruit flies in Argentina: Historical review, current status, and future trends for developing a parasitoid mass-release program. Insects 3: 870-888.

OVRUSKI SM, WHARTON RA, RULL J \& GUILLÉN L. 2007. Aganaspis aluja (Hymenoptera: Figitidae: Eucoilinae), a new species attacking Rhagoletis (Diptera: Tephritidae) in the Neotropical Region. Fla Entomol 90(4): 626-634.

PRADO PI, LEWINSOHN TM, ALMEIDA AM, NORRBOM AL, BUYS BD, MACEDO AC \& LOPES MB. 2002. The fauna of Tephritidae (Diptera) from capitula of Asteraceae in Brazil. Proc Entomol Soc Wash 104: 1007-1028.

QGIS DEVELOPMENT TEAM. 2016. QGIS Geographic Information System. Open Source Geospatial Foundation Project. http://qgis.osgeo.org.

SAVARIS M, LAMPERTA S, LORINI LM, PEREIRA PRVS \& MARINONI L. 2015. Interaction between Tephritidae (Insecta, Diptera) and plants of the family Asteraceae: new host 
and distribution records for the state of Rio Grande do Sul, Brazil. Rev Bras Entomol 59: 14-20.

SAVARIS M, MARINONI L \& NORRBOM AL. 2016. Family Tephritidae, p. 596-621. In: Wolff M, Nihei SS and Carvalho CJB (Eds), Catalogue of Diptera of Colombia. Zootaxa 4122 (1): 1-949.

STRAW NA. 1989a. Taxonomy, attack strategies and host relations in flowerhead Tephritidae: a review. Ecol Entomol 14: 445-462.

STRAW NA. 1989b. The timing of oviposition and larval growth by two tephritid fly species in relation to hostplant development. Ecol Entomol 14: 443-454.

TURNER C, SOBHIAN R, JOLEY D, COOMBS E \& PIPER G. 1994. Establishment of Urophora sirunaseva (Hering) (Diptera: Tephritidae) for biological control of yellow starthistle, Centaurea solstitialis in the western United States. PanPac Entomol 70: 206-211.

VAN DRIESCHE R, HODDLE M \& CENTER TD. 2008. Control of pests and weeds by natural enemies: an introduction to biological control, $1^{\text {st }}$ ed., Blackwell Pub, Malden, MA.

WOODBURN TL. 1993. Host specificity testing, release and establishment of Urophora solstitialis (L.) (Diptera: Tephritidae), a potential biological control agent for Carduus nutans L., in Australia. Biocontrol Sci Techn 3: 419-426.

ZACHARIADES C, DAY M, MUNIAPPAN R \& REDDY GVP. 2009. Chromolaena odorata (L.) King and Robinson (Asteraceae). In: Muniappan R, Reddy GVP and Raman A (Eds), Biological control of tropical weeds using arthropods. Cambridge University Press, Cambridge \& New York, p. 130-162.

\section{How to cite}

MARTINEZ FJ, NORRBOM AL, SCHLISERMAN P \& CAMPANELLA MV. 2020. Tephritidae flies associated with Chuquiraga avellanedae (Asteraceae) in Patagonia, Argentina. An Acad Bras Cienc 92: e20191524. DOI 10.1590/0001-3765202020191524.

Manuscript received on December 11, 2019;

accepted for publication on May 04, 2020

FERNANDO J. MARTINEZ ${ }^{1,2}$

https://orcid.org/0000-0003-2626-308X

ALLEN L. NORRBOM ${ }^{3}$

https://orcid.org/0000-0002-5854-089X

\section{PABLO SCHLISERMAN ${ }^{4}$}

https://orcid.org/0000-0002-1376-9471

\section{MARÍA VICTORIA CAMPANELLA}

https://orcid.org/0000-0003-4416-4747

${ }^{1}$ Grupo de Ecología de Comunidades Áridas/GECoA, Instituto Patagónico para el Estudio de los Ecosistemas Continentales, IPEEC-CONICET, Boulevard Brown 2915, 9120 Puerto Madryn, Chubut, Argentina ${ }^{2}$ Universidad Nacional de la Patagonia San Juan Bosco, Boulevard Brown 3700, 9120 Puerto Madryn, Chubut, Argentina ${ }^{3}$ Systematic Entomology Laboratory, USDA, ARS. P.O. Box 37012, MRC 168, 20013-7012 Washington, DC, USA

${ }^{4}$ Centro de Investigaciones y Transferencia de Catamarca, CITCA-CONICET/UNCA, Prado 366, 4700 Catamarca, Argentina

Correspondence to: María Victoria Campanella

E-mail:campanella@cenpat-conicet.gob.ar

\section{Author contributions}

FJM and MVC conceived the idea, collected data and wrote the first draft of the manuscript. ALN identified specimens. FJM, ALN, PS and MVC contributed substantially to revisions.

\section{(cc) BY}

